\title{
Por uma escola inclusiva ou da necessária subversão do discurso (psico)pedagógico hegemónico
}

Leandro de Lajonquière'

\section{Resumo}

Com vistas a indagar o funcionamento e o estado da implantação da "escola inclusiva", o texto apresenta e desenvolve a noção da ilusão (psico)pedagógica. Esta é considerada peça-chave do ideário pedagógico naturalizante. Assim, afirma-se que o naturalismo pedagógico de antanho que estabelecia uma diferença essencial entre "normais" e "anormais" - suficiente para que estes ficassem impedidos de ir às escolas comuns -, hoje em dia, dá paradoxalmente lugar à ideia de "necessidades educativas especiais", proposta pela Declaração de Salamanca (1994). Essa noção dá margem, por sua vez, à prática de "laudar" crianças. Tal gesto, particularmente generalizado no Brasil, acaba empobrecendo a experiência escolar das crianças, condenando-as à condição de "excluídas do interior". Propõe-se, então, no contexto dos estudos psicanalíticos em educação, a subversão epistemológica do ideário naturalizante, responsável pelos entraves impostos ao acontecimento de uma educação que se preze.

Palavras-chave: Educação inclusiva. Psicanálise e educação. Pensamento naturalista. Essencialismo pedagógico. Psicopedagogia.

À Maud Mannoni

In memoriam

\section{O discurso (psico)pedagógico hegemônico}

No contexto do novo ideário escolar dito da educação inclusiva no Brasil, a julgar pelas informaçóes que nos chegam pelos orientandos a respeito

\footnotetext{
I Psicanalista, docente nas universidades de Paris 8 Vincennes Saint-Denis (França) e de São Paulo (Brasil). E-mail: Ide-lajonquiere@univ-paris8.fr
}

\section{$(\infty)$ Er}

Direito autoral e licença de uso: Este artigo está licenciado sob uma Licença Creative Commons. Com essa licença você pode compartilhar, adaptar, para qualquer fim, desde que atribua a autoria da obra, forneça um link para a licença, e indicar se foram feitas alterações. 
das escolas e colégios, sobretudo da rede pública de ensino da cidade de São Paulo, parece não serem poucos os alunos que, apresentando notas baixas nas avaliaçóes, passam a ser requalificados como "alunos de inclusão". Dessa forma, estes alunos que no passado século XX teriam sido encaminhados com vistas a serem "avaliados" e/ou "tratados" e/ou "simplesmente rotulados médico/psicologicamente" como "doentes" ou "carentes" de alguma "capacidade maturativa”, conforme mostraram os já clássicos estudos de Maria Helena Sousa Patto (1984, 1993), hoje em dia permanecem no interior das escolas e passam a engrossar o grupo dos "incluídos". Tal grupo é formado por todos aqueles que, sendo "portadores de alguma deficiência" ou apresentando alguma "necessidade educativa especial", eram até algum tempo atrás excluídos do ofício das escolas e encaminhados quando possível para "escolas especiais".Sobre o particular, poder-se-ia afirmar que se trata de um avanço tanto societário quanto no terreno das ideias pedagógicas, pois a criança que hoje apresenta "problemas na escola" não é mais expulsa, tampouco rotulada como "deficiente" como antes. Agora pensa-se que cada criança "é como é" e, portanto, todas são "incluídas” em nome da "diferença" que cada uma porta. No entanto, é sabido que, para além das exceçôes sempre devidas ao profissionalismo e à implicação ética de não poucos, o grupo dos "incluídos", constituído pelos "excluídos de outrora" e por aqueles reclassificados "incluídos", nos dias de hoje não participa de fato da experiência escolar como os outros, isto é, a maioria. Esta afirmação não deve ser entendida no sentido de que cada um dos mortais tira proveito de uma experiência de vida de forma sempre singular - isto é ou deveria ser óbvio -, mas infelizmente no sentido de que estes "incluídos" não passam hoje, de fato, de "excluídos do interior", conforme a expressão utilizada por Bourdieu e Champagne (1993) para se referirem à situação dos jovens oriundos de famílias pobres no "colégio único" francês, instaurado no final da década de $1970^{2}$.Os "incluídos-excluídos do interior" ficam na borda da experiência escolar reservada à grande maioria considerada "normal" - palavra atualmente proferida em voz baixa na maioria das vezes. Por sinal, quando os profissionais da educação a proferem em

2 Antes da instauração do colégio único, o ensino secundário na França era dividido em especialidades curriculares. Os jovens de classes populares eram maioria no ensino à vocação profissionalizante. 
público sentem-se obrigados à correção; faz-se curioso, porém, que estes parecem não encontrar outro termo para substituí-la. $\mathrm{O}$ termo lhes falta dando a entender assim que, pesem as aparências em contrário, o fantasma do "normal" continua onipresente no ideário pedagógico.

O fato de o novo "aluno de inclusão" não ser mais avaliado escolarmente e, portanto, não estar sujeito à reprovação é um detalhe. Não proponho tampouco o contrário. A meu entender, a questão é bem outra. $\mathrm{O}$ fato de a criança que apresenta "problemas de aprendizagem" ser rapidamente convertida num "aluno de inclusão" é, retomando a distinção freudiana sobre os benefícios do sintoma, um simples benefício secundário do agenciamento do ideário dito da educação inclusiva; mas não por isso desprovido de efeitos, como tentarei mostrar neste ensaio. Por outro lado, sendo as escolas perseguidas pelo furor avaliativo governamental brasileiro, distribuidor de bonificações, este arranjo de circunstância para "inglês ver" - a requalificação em "aluno de inclusão" - não deveria nos surpreender. A questão central e trágica é que o "incluído" fica de fato "excluído" de antemão da experiência escolar.

A demanda escolar endereçada ao "incluído" é diferente a tal ponto que cabe se perguntar se esta ainda merece ser qualificada como escolar. Talvez não passe de uma pseudodemanda escolar. Dos "incluídos" só se espera que não venham a incomodar o desenvolvimento daquilo que se supóe ser "uma aula normal", ou seja, aquela que deve responder a uma programação psicodidática considerada adequada à clientela "incluída desde sempre por natureza" aos chamados normais, àqueles que supostamente assim nasceram para ir à escola, para além de todo e qualquer artifício societário. Nesse sentido, cabe se perguntar até que ponto, apesar das boas declaraçóes em contrário, ainda se espera que estas crianças venham a tirar algum proveito da experiência escolar. Isso, por sua vez, não quer dizer que os profissionais da educação acabem promovendo de forma deliberada este tipo de segregação. Deixando de lado alguns cínicos de plantão que sempre há, mas que, em princípio, não são os que de fato labutam todos os santos dias com as crianças, a segregação do "incluído" da experiência escolar é um efeito de sistema, ou seja, é o resultado da própria forma como a inclusão escolar vendo sendo pensada para além das boas vontades.Cada "incluído" 
é incluído em virtude de portar alguma diferença que diz de sua maneira essencial de ser, devidamente "laudada"; e hoje em dia de preferência por algum médico: disléxico, autista, hiperativo, ciclotímico etc. Dessa forma, tudo o que os "laudados" façam ou deixem de fazer passa a ser lido como a manifestação de uma essência diferente. O aluno "laudado" sempre é sonhado ou esperado num mesmo e único lugar. Ele é o destinatário de uma demanda que o fixa num lugar fixo, que pede para ele ser sempre aí onde está sendo esperado (FANIZZI; LAJONQUIÈRE, 2020). A sua suposta diferença existencial parece ser hoje "respeitada", mas de fato não muito. Ela continua sendo o velho "desvio normativo" ou mesmo o "defeito" de antes. Ou seja, a marca de uma distância com relação a um parâmetro existencial considerado "normal” e, portanto, "natural". Tal padrão é produzido por uma força ou um saber, independente do agir humano no campo da palavra e da linguagem, chamado natureza (ROSSET, 1973; LAJONQUIĖRE, 1999). Em suma, o "laudado" pela ciência vê a sua existência ser reduzida ao real de uma natureza sempre suposta.

Nesse contexto, os "incluídos", por quaisquer que sejam as razóes, tornam-se os "excluídos do interior" da experiência escolar. Pareceria ser esse o preço a ser pago pela tolerância da "diferença" no cenário escolar. Sob tal lógica, a diferença passou a ser reconvertida naquilo que o imaginário pedagógico parece não poder pensar de outra forma, isto é, num costumeiro desvio normativo. Assim, fala-se de diferença, mas continua-se a pensar em termos de desvio contranatural, bem como a tratar a criança como se fosse uma deficitária a ser "remediada” compulsivamente ou, simplesmente, alguém a ser ignorado.

Os professores e outros profissionais que intervêm na educação sabem, de certa forma, que infelizmente a dita educação inclusiva de inclusiva tem, na maioria das vezes, apenas o nome. Eles costumam dizer que a "inclusão não acontece". E por quê? As razóes esgrimidas são ora a "falta de recursos", ora a "falta de preparaçáo", ora as duas razóes ao mesmo tempo, em particular - é claro - quando se trata da rede pública de ensino no Brasil. Obviamente, não pretendo dizer o contrário. Todo recurso financeiro destinado à educação é sempre pouco, assim como toda formação 
profissional é simplesmente o início de um processo de aperfeiçoamento constante ${ }^{3}$. Nesse sentido, o que se está a dizer quando se afirma que a "inclusão não acontece"? O que seria o acontecer de uma inclusão? De quais recursos se tratam quando dizemos sentir a falta deles? $\mathrm{O}$ que viria a ser "estar preparado" para participar da educação de uma criança?

Como se continua a pensar em termos naturalistas, a esgrimida diferença no ser da criança, hoje respeitada pelo ideário inclusivo, acaba sendo o mesmo desvio normativo de sempre. Assim, a sonhada inclusão que nunca chega náo seria outra que o mesmíssimo apagamento no real do desvio. Isto é precisamente impossível por conta do círculo vicioso instaurado pelo pensamento naturalista. A única saída é a sua pura e simples subversão epistemológica. É como, se por ventura, um suposto pecador pudesse vir um dia a deixar de sê-lo aos olhos de uma religião qualquer. Dessa forma, impóe-se encontrar um outro elemento capaz de nos orientar na experiência de inclusão além de toda a transcendência naturalista. Este outro elemento possibilitaria recolocar em outros termos os recursos que faltam, sempre sonhados num registro técnico-imediatista: como fazer a criança ficar quieta? Como fazer para que ela repita o que estou a ensinar sem muitas voltas?

Igualmente no que tange à ladainha da formação não dispensada, em primeiro lugar, deveríamos indagar o quanto da própria posição subjetiva do enunciador se diz nesta frase: não fui formado. O locutor dá, de fato, a entender que um outro detentor do saber recusou-se a formá-lo à sua própria imagem e semelhança. Por outro lado, como se pode "ser ou estar bem formado" de antemão para "nadar de braçada" numa experiência que ainda não teve lugar pela simples razão que os personagens que irão vivê-la não se encontraram? Novamente, constata-se que a dita formação pedagógica é sempre pensada no registro de uma técnica de controle, mas nunca nos termos de se estar - ou náo - subjetivamente disposto a endereçar a palavra a uma criança, disposição sem a qual experiência educativa nenhuma se descortina no horizonte. Neste contexto, afirmo que o fato de estarmos hoje em dia a reconverter os alunos antes ditos com problemas

3 Costumo dizer que a profissão docente não é para qualquer desavisado. O ofício exige, de fato, o docente no íntimo de sua existência como falasser [parlêtre], retomando o neologismo de Jacques Lacan para se referir ao ser falante. 
de aprendizagem em "alunos de inclusão" não é um acidente de percurso ou um derivado de uma interpretação errada do ideário inclusivo hoje vigente. Os descaminhos atuais são a prova de suas próprias limitaçóes que, por sua vez, não são outras que as do mesmíssimo discurso (psico)pedagógico hegemônico (LAJONQUIÈRE, 1999) que prescreve a forma e qualidade da experiência escolar de toda e qualquer criança. Assim, trata-se de examinar a sua lógica de funcionamento embasada na suposta esperteza/experiência de saberes mais ou menos científicos com vistas a colocarmos a experiência de as crianças frequentarem as escolas sobre o eixo de uma ética do sujeito (LACAN, [1959-1960] 1986a, [1969] 1986b; IMBERT, 1993). Todas as crianças, para além da suposta "especialidade" e de suas supostas "necessidades educativas", conforme a nomenclatura hoje em voga, tem a ganhar com a subversão epistemológica deste discurso (psico)pedagógico hegemônico.

\section{A ilusão d' $A$ Criança e a falta de proporção entre adultose crianças}

Uma simples conversa com os candidatos - ainda em formação - a professores do ensino básico nos informa sobre as crenças pedagógicas vigentes. Eles afirmam, por exemplo, que a escola brasileira está hoje em crise e que esta se exprime pela "falta de autoridade". Alguns anos atrás, eles diziam em uníssono que o que complicava o exercício profissional eram os "problemas de aprendizagem". Trata-se de um descolamento interessante que diz algo sobre os novos tempos políticos: a autoridade e sua hipotética falta ganharam destaque no imaginário social brasileiro. Mas voltemos ao que dizem estes jovens. Incitados a dizerem um pouco mais, afirmam que antes não era assim, pois havia a "autoridade" que precisamente agora falta. Interrogados sobre esta suposta falta de autoridade, respondem que as crianças não obedecem nas escolas devido a uma série de razóes, quais sejam: ou os saberes transmitidos não chamam mais a atenção delas, ou a modalidade do ensino é inadequada às "crianças diferentes de hoje". Se ainda questionados sobre o porquê de os saberes escolares não "colarem" mais como antes, duas razões são elencadas: ou eles não são mais úteis no mundo atual, ou são as crianças que apresentam algum tipo de impedimento para virem a se interessar ou "agarrar" nos conteúdos ensinados. Este 
impedimento resultaria ou de uma "incompetência" ou "incapacidade" da própria criança "com problemas de aprendizagem ou de comportamento", ou de uma inadequação da lógica escolar de ensino à singularidade "neuro", "psico" e/ou "social" inerente ao ser da criança. A tese da inadequação do ensino escolar à condição neurológica, psicológica ou social da criança desponta, então, como sendo "a razão das razóes” do insucesso educativo. Como vemos, aqui reencontramos o conhecido reclamo da falta do método adequado para lidar com "as crianças com problemas" de antanho. O raciocínio mais ou menos circular destes jovens profissionais rediz aquilo que os pais das crianças também dizem, bem como aquilo que os telejornalistas veiculam quando da educação, da sua propalada crise e da escola se trata. Este discurso pedagógico hegemônico que delimita os contornos imaginários da experiência escolar das crianças é, por sua vez, fruto da somatória mais ou menos desordenada de ideias oriundas de diversos campos do saber no decorrer dos tempos.

O império nos imaginários pedagógicos de certas ideias em detrimento de outras é revelador da circulação de determinadas tramas conceituais em sintonia com diversos momentos da história e da política nacionais, nos quais o fator contingencial tampouco deixa de estar presente 4 . Assim, acabam primando certas crenças oriundas das ciências médicas, psicológicas e sociológicas em detrimento de outras ${ }^{5}$. No entanto, mal que isso pese aos expertos na matéria que sonham com argumentos cartesianos, os imaginários pedagógicos também dizem de idiossincrasias existencialistas não tão claras e distintas. Para um psicanalista, dizem de como é vivida a diferença entre adultos e crianças, de como "se pensa" que estas deixam de ser infans passando a conquistar um lugar de palavra em nome próprio no campo da palavra e da linguagem (LAJONQUIÈRE, 2006). Além de

4 Para um debate exploratório sobre as diferenças entre os imaginários pedagógicos brasileiro, argentino e francês, consultar: Lajonquière, 2019.

5 Os desenvolvimentos psicanalíticos também deram suas contribuições, às vezes interessantes e outras infelizmente não tanto por uma série de razões que fogem ao escopo deste texto. No entanto, é líquido e certo que o pensamento psicanalítico, para além de ter dado lugar ao movimento intelectual da pedagogia psicanalítica, entre 1908 e 1936, não embasou até o momento nenhum discurso (psico)pedagógico que viesse a se tornar hegemônico. Talvez seja pelo simples fato de que a psicanálise sabe, à sua maneira, da impossibilidade de haver proporção entre adultos e crianças e, portanto, do caráter ilusório de toda pretensa aplicação técnica (LAJONQUIÈRE, 2017). 
contingências corriqueiras, os imaginários pedagógicos se estruturam, em última instância, em torno de um ponto cego que escapa à simbolização, assim como Freud dizia que todo sonho perde-se numa espécie de umbigo insondável. Dessa forma, todo imaginário pedagógico diz de como o mundo adulto experimenta e sonha sua relação paradoxal com a criança. Sobre a relação com a criança, os adultos tanto querem saber quanto não querem saber que não se pode saber que não há saber sobre ela (LAJONQUIËE, 1999). Em outras palavras, tanto querem saber quanto não saber que não há proporção entre adultos e crianças.

O fato de falarmos em termos de falta de proporção entre as geraçôes visa à subversão do raciocínio naturalista que dá lugar às psicologias do desenvolvimento clássicas, coluna vertebral do discurso (psico)pedagógico hegemônico no Brasil. Para estas, a condição adulta está em última instância contida em potência na criança; portanto, há entre eles uma proporção da mesma forma que a raiz quadrada de quatro é dois. Entretanto, o suposto caráter adulto dividido pela suposta menoridade psicológica das crianças resulta em um valor indeterminado: o infantil no sentido freudiano (LAJONQUIĖRE, 2006, 2010). Assim, nossa tese sobre a falta de proporção assinala não haver comunicabilidade entre os lugares de enunciação do adulto e da criança no campo da palavra e da linguagem. Entre ambas as posiçóes enunciativas aninha-se um impossivel de se dizer do qual o adulto nada quer saber (LAJONQUIĖRE, 2010).

O irredutível não querer saber de que não há saber sobre a relação com a criança, faz com que o mundo adulto se iluda com formulaçóes pedagógicas como sendo bem fundadas em ideias claras e distintas, caucionadas pela ciência e seus expertos. Esse não querer saber da impossibilidade que se aninha em toda relação com uma criança concreta é a matéria-prima para a construção de uma criança de ficção científica chamada d'A Criança (LAJONQUIÉRE, 2008a, 2008b, 2010). Por outro lado, para um psicanalista, essa insistência em não querer saber que não há proporção não é sem consequências para as crianças de carne e osso. De fato, Freud ([1929] 1990d, p. 3060) afirmou que "[...] a educação se comporta como se enviasse as crianças para uma expedição polar vestidas com roupas de verão e equipadas com os mapas dos lagos lombardos". O mundo adulto parece 
nunca acertar o alvo quando da educação das crianças se trata. Mas quanto há de inevitável nisto, ou seja, da própria condição humana e, portanto, faz-se inerente ao desdobrar de toda educação e quanto corresponde aos efeitos deletérios produzidos pelo tecnocientismo pedagógico atual?

Uma criança bem pode conseguir fugir de semelhante funesta empresa turística polar, sobrevivendo à sua família e à escola. Isso não deve nos surpreender, pois a cada criança sempre cabe inverter, não sem esforço, demandas educativas adultas, mais ou menos enlouquecidas ou não, de ontem, de hoje e de amanhã. Como tal coisa é possível? De fato, tudo depende das chances de uma criança vir a situar o desejo no horizonte da experiência educativa, isto é, a castração no Outro, como dizemos em psicanálise. Essa operação cobra de toda criança uma singular implicação subjetiva. Nada pode vir a poupá-la de realizar o trabalho psíquico de se confrontar à castração ou à falta de saber no Outro. Quando uma criança mais ou menos fracassa nesse intento, fica à mercê de uma experiência social empobrecida.O imaginário pedagógico passou há um século a considerar, ao instar do movimento europeio conhecido como pedagogia psicanalítica e das ideias escolanovistas, a criança e tudo aquilo que ela é ativamente capaz de fazer. Porém, com o tempo o lugar da criança acabou infelizmente deslocando-se. O imaginário perdeu o entusiasmo inicial pela criança, passando a mirar essencialmente as supostas idiossincrasias "neuro", "psico" e/ou "social" de uma criança genérica - A Criança. As idiossincrasias deste novo ser de ficçáo científica tornaram-se cada uma a seu turno - ou até simultaneamente - peças-chave no processo de aprendizagem. A prestança d'A Criança dos expertos se fez ao custo da perda da dignidade humana que as crianças de carne e osso tinham conseguido conquistar no decorrer da história (ARIÈS, [1960] 1973).

Boa parte dos estudos em educação proclamam de forma expressa que o ensino escolar e/ou o próprio dispositivo institucional devem adequar-se e/ou ajustar-se À Criança, sob pena de se promover o insucesso da empreitada pretensamente pedagógica. Assim temos que o ajuste ou a adequaçáo entre a intervenção educativa adulta e a realidade idiossincrática infantil de natureza "neuro", "psico", e/ou "social” é tanto possível quanto necessário. Todo e qualquer resultado decorre do grau de sucesso ou insucesso desse 
ajustamento. Assim, todo "fracasso educativo" reclama uma maior dose de saber experto com vistas à promoção de um melhor ajuste. Essa crença particularmente embalada nos anos 1990 no Brasil pelos saberes psicológicos autodeclarados piagetianos e/ou vigotskianos foi chamada, na esteira da reflexão freudiana sobre o estatuto metapsicológico das crenças religiosas (FREUD, [1927] 1990c), de ilusão (psico)pedagógica (LAJONQUIÈRE, 1999). Na época, não se tratava de discutir se as pretendidas aplicaçóes pedagógicas das teses piagetianas e/ou vigotskianas eram mais ou menos pertinentes $^{6}$, mas de indagar que desejo animava semelhante projeto de se formatar, a partir de proposições psicológicas reputadas científicas, parâmetros para uma nova prática pedagógica capaz de tirar a escola brasileira do marasmo no qual se encontrava. Além do fato em si questionável de se buscar justificar uma política de estado em saberes científicos ${ }^{7}$, o que pretendia - e ainda pretendo - era assinalar a natureza descabida da crença tanto na possibilidade quanto na necessidade de se adaptar ou ajustar científico-tecnicamente a intervenção educativa adulta a uma suposta natureza infantil. Trata-se da crença numa harmonia preestabelecida. Isto constitui uma ilusão (psico)pedagógica que nada quer saber da impossível proporção entre um adulto e uma criança. Trata-se como toda ilusão de uma crença, independente do cânon científico vigente numa época determinada, animada ou sustentada por um desejo. Neste caso, o desejo que anima a ilusão (psico)pedagógica é um desejo de não saber da impossível proporção entre adultos e crianças, ou seja, trata-se de um voto de dar consistência À Criança. Este desejo de não desejar não é de bom augúrio na educação.A pretensão, hegemônica no Brasil nos anos 1990, de se outorgar uma justificação psicológica à educação pode ser substituída ou complementada, dependendo das circunstâncias históricas e dos países, por teses sociológicas de diversos calibres ou por saberes médicos os mais variados. Por exemplo, na França, o ideário pedagógico tem o hábito de reconverter a seu proveito não poucas teses sociológicas. Assim foi, em particular, nos anos 1970 e 1980 . Porém, após certo tempo, o destaque passou a ser dado

6 Isso foi feito na época no interior dos respectivos campos de estudo. Assim, havia piagetianos/vigotskianos que viam ora com bons ora com maus olhos o que outros colegas do mesmo campo estavam na época a implementar pedagogicamente.

7 Isto não justifica, por outro lado, que os governantes convertam a ignorância numa virtude. 
aos avanços da genética e das ciências cognitivas, sem por isso chegar à medicalização à moda norte-americana e brasileira baseada na distribuição generalizada de medicamentos. Não me parece oportuno, no entanto, falar em termos de ilusão (sócio)pedagógica ou (médico)pedagógica. O prefixo "psico" além de denotar os saberes psicológicos diz fundamentalmente da crença tanto na necessidade quanto na facticidade em se ajustar ou adequar à intervenção educativa do adulto àquilo que se supóe ser uma individualidade essencial dada, seja por razóes psicológicas, societárias ou biológicas. Se na tentativa de dar "embasamento" ou justificação às práticas educativas recorre-se à psicologia ou a boas doses de ritalina, é irrelevante para nosso raciocínio. O que me interessa como psicanalista é analisar essa insistência em querer justificar aquilo que em última instância é injustificável cientificamente: o endereçamento de uma palavra educativa a uma criança de carne e osso. O caráter injustificável de toda e qualquer educação é parte constitutiva do ato educativo. Recusar a impossibilidade de justificaçáo implica o aborto da potestade performativa de uma educaçáo que se preze. Meu objetivo é precisamente recuperar o caráter performativo inerente ao laço educativo que o naturalismo pedagógico visa a obturar.

\section{A palavra e o lugar do sujeito na educação}

Valemo-nos da palavra para pedir ajuda aos outros, para dar ordens, para expressar os nossos sentimentos, para fazer rir ou chorar alguém, para convidar as pessoas a brincar, para dar a nossa palavra ou para exigir que os outros cumpram a sua. Fazemos tudo isso de forma habitual. Porém, aprender a falar uma língua qualquer implica um trabalho psíquico decisivo que entranha em si a conquista de um lugar de enunciaçáo no campo da palavra e da linguagem. De fato, quando aprendemos a falar, estamos a nos dizer numa língua. Não há fala que possa ser proferida a partir de um não lugar, tampouco ela não pode não ser endereçada a um "outro". Por isso mesmo, prefiro dizer que o locus habitado pelo sujeito é aquele do campo da palavra e da linguagem e não simplesmente da fala e da linguagem. Assim, cabe dizer que a comunicação entre máquinas e entre animais acontece fora do registro da palavra, ou seja, de uma fala endereçada. Nesse sentido, o fato de uma criança vir a endereçar a palavra é o resultado ímpar de uma educação primordial no tempo da infância. Toda criança que chega 
à vida, deve ainda entrar no mundo. É necessário que a porta do mundo venha a se abrir perante o bebê recém-chegado para que um dia ele possa "dizer a que veio". Esta porta não é outra que o desejo no horizonte da experiência. Para tanto, a criança se aplicará com maior ou menor sorte a inverter a demanda educativa parental que, em última instância, sempre lhe pede que venha a completar aquilo que de outra forma sempre falta ao casal.Do balbucio inicial até ao uso do pronome pessoal "eu" - como quando a criança diz "eu tenho fome" -, tendo previamente passado pela referência a si próprio na terceira pessoa - "Pedrinho tem fome" -, um bebê lançado à palavra deixa de ser tal para, assim, converter-se numa criança pequena capaz de brincar que "era" uma pessoa grande que num futuro "terá sido", mas que "ainda não é" - como quando convida o seu amiguinho: "Vamos brincar que éramos bombeiros?". Esta transformação, que somente um ser humano pode experimentar, articula-se no campo da palavra e da linguagem e implica a conquista de um lugar para si próprio no tecido discursivo. Se tal proeza tornou-se possível é porque o pequeno sujeito suportou experimentar, na própria carne, o desdobramento desse processo discursivo que é a operação inconsciente de identificação ao S1 Significante Mestre - destacado do campo do Outro, e a sua consequente remissão a um S2 - Saber inconsciente -, relançada uma e outra vez em toda enunciação, conforme o raciocínio psicanalítico lacaniano. $\mathrm{O}$ bebê aventura-se nessa experiência embalado, por um lado, pelo Outro materno primordial e, por outro, pela "apetência simbólica" (CRESPIN, 2010) que designa no registro simbólico a orfandade biológica radical própria às criaturas sapiens (LAJONQUIÈRE, 2010).

O lugar do sujeito num discurso não é o resultado nem da maturação biológica, nem da imitação de comportamentos supostamente garantida por uma aptidão biológica primitiva. Ele resulta de uma operação inconsciente de identificação que envolve um duplo e mesmo movimento: primeiro, o fading ou desvanecimento do sujeito pelo efeito de colagem a um Significante do Outro ou de alienação no sentido e, segundo, a separação ou perda do sentido anteriormente conquistado, graças à operação psíquica de recalque original do Significante Um (LACAN, [1968-1969] 2006). O fato de a identificação simbólica vir a vingar, pois nada a garante de antemão, depende do entrelaçamento de duas condiçóes igualmente 
necessárias: por um lado, que o bebê suporte a experiência da tensão imaginária com o "Eu Ideal” formatado pela demanda parental e, por outro, que o adulto consiga dar testemunho do desejo em pauta na sua relação com a criança. Estas duas condiçóes possibilitam que seja evacuado da demanda adulta o excesso de gozo ou o mais a gozar que ela comporta. Este é "cuspido" fora pela criança como objeto a (LAJONQUIËRE, 1993, 2010). Quando tudo isso ocorrer a contento, isso que não é outra coisa que um algoritmo educativo operante no discurso, instaura-se uma ressonância entre os personagens (LAJONQUIÈRE, 2011), que possibilita à criança avançar na empresa de se fazer um lugar por-si e para-si no mundo, abrindo-se caminho entre a inibição e a angústia (FREUD, [1925] 1990). Porém, não há garantias. O processo pode não avançar no seu desdobramento. Uma criança pode ficar travada no seu caminhar, pode não engatar em ressonância alguma.

O resultado da conquista de um lugar de sujeito de palavra num discurso deve ser creditado em partes iguais tanto à criança quanto ao adulto. Trata-se de um resultado a priori indeterminado, mas que, na contabilidade estabelecida pela psicanálise, será creditado na coluna "escolha do sujeito"; este, não tendo idade, não é nem a criança nem o adulto. Em suma, "quem" escolhe é o mesmíssimo sujeito do inconsciente. No decurso desta operação, cabe ao adulto, segundo o esquema óptico proposto por Lacan (1953-1954) para pensar a experiência especular, "olhar" na direção certa, isto é, dirigir-se ao bebê numa posição que diga do desejo em pauta no ato educativo. Se o adulto náo conseguir manter este ato testemunhal de natureza performativa, a educação primordial torna-se um fato de difícil acontecimento (LAJONQUIÈRE, 1999). Ou seja, não se pode dizer que a educação seja a priori impossível, mas o trabalho que a criança é conclamada a realizar exigirá dela um esforço adicional. A criança pode, ou não, aceitar o desafio. É impossível tanto sabê-lo antecipadamente quanto conhecer o preço psíquico a ser pago por semelhante façanha ou vitória de Pirro. Por outro lado, embora o adulto venha a cumprir o seu papel, qual seja, fazer os $50 \%$ que lhe correspondem, a criança bem pode não fazer a sua parte nesta história, isto é, os outros $50 \%$, na conquista de um lugar de palavra. E por que não? Infelizmente, é impossível de sabê-lo. É possível, por exemplo, que alguma disfuncio- 
nalidade biológica adquira um valor tal dentro do conjunto de elementos que compóem a experiência de vida que acabe por se converter num obstáculo intransponível para a criança. Mas a chamada disfuncionalidade nunca é um impedimento per se à emergência de um sujeito na criança. Ela apenas constitui-se como tal a posteriori. Por conseguinte, a biologia nunca é a causa, mas sim um limite. Mais ainda, a causação não é linear, tampouco mecânica. Ela é estrutural, de modo que um sujeito do desejo é sempre o efeito de um conjunto que náo se reduz à soma dos ditos fatos ${ }^{8}$; assim, esta deve ser pensada em termos de experiência vivida no interior do campo da palavra e da linguagem (LAJONQUIÈRE, 2017b, 2019).

Dirigir a palavra a uma criança entranha muito mais do que a exposição de uma criança a qualquer tipo de verbalismo. Nenhum bebê conquista um lugar de palavra apenas por estar exposto durante horas a fio à televisão ou ao rádio. O adulto tem de "falar com" a criança, como costumava dizer Françoise Dolto, deve dirigir-se a ela de forma que ela sinta ser a destinatária íntima da palavra. Por vezes o adulto pode não falar uma língua oral, ou talvez a criança não consiga ouvir ou ver o adulto $^{9}$ que a ela se endereça; isso, entretanto, náo impede o adulto de "falar com" a criança, tampouco impede à criança saber-se reconhecida como sujeita ao desejo. O que conta então na educação primordial é o fato de o adulto dirigir-se à criança testemunhando a castração em pauta na própria educação. A criança se verá confrontada à questão de saber o que o adulto quer dela. Assim este se torna um representante do grande Outro, como dizemos na psicanálise. Em suma, o que importa é que a educação primordial entranhe um desejo que não seja anônimo (LACAN, [1969] 1986b). No fundo, é o desejo que eleva o vínculo interativo bebê-mundo-adulto à categoria de linguagem ou função significante, que torna possível a sujeição do bebê a um lugar num discurso. O desejo é a mesmíssima ressonância entre os personagens que "fazem" a experiência, e o Outro aquilo que podemos qualificar como sendo a caixa de ressonância.O processo causal de um sujeito de palavra não só não está escrito

8 O raciocínio psicanalítico não deve ser confundido com um psicologismo fatorialista sofisticado.

9 Cabe precisamente recordar a história da pequena Helen Keller surda e cega que aos sete anos "aprende" a falar (LAJONQUIÈRE, 2014). 
antecipadamente, como também é parasitado por mal-entendidos. Ele toma forma à medida que se desdobra, integrando em seu seio esses curtos-circuitos discursivos inevitáveis. Nesse sentido, a conquista de um lugar de sujeito no campo da palavra e da linguagem implica se haver com os mal-entendidos no interior de uma verdadeira carreira de obstáculos.

Quem tem a culpa desses curtos-circuitos ou acidentes de percurso sobrevindos na educação primordial? A mãe? $\mathrm{O}$ pai? $\mathrm{Ou}$ a própria criança? Ninguém tem culpa! No entanto, isso não significa que estes se tratem de desígnios divinos ou de determinação genética. Basta lembrar que a distinção biológica dos sexos, nem mesmo ganhando reforço divino, consegue determinar a priori o que fazer com ela na vida dita amorosa. Assim sendo, só há curtos-circuitos ou mal-entendidos na codificação de um processo que diz respeito à implicação subjetiva e inconsciente dos participantes no desdobramento de uma educação primordial no campo da palavra e da linguagem. O processo causal de um sujeito é autoescrito ou estrutural, ou seja, ele escapa à vontade pedagógica dos participantes na educação. Porém, ele exige paradoxalmente a participação dos mesmos em carne e osso. A somatória das implicaçôes subjetivas e inconscientes dos personagens envolvidos na história, que não se reduz ao "aqui e agora", constitui o desejo do Outro. Em suma, o desejo inconsciente não é nem a boa nem a má vontade ou competência técnica de ninguém, como hoje se costuma pensar.

A integração desses mal-entendidos faz a posição do sujeito no campo da palavra e da linguagem. A experiência banal de um mal-entendido na conversação cotidiana nos prova que ele pode tanto impedir a prossecução do diálogo, quanto animar o desdobramento deste, ou seja, pode "dar o que falar". Neste caso, cabe dizer que os personagens estabelecem ou entram em certa ressonância. Assim, seguindo a comparação, podemos afirmar que uma criança tanto pode continuar a circular no laço social, isto é, entrar em ressonância com outros, como, do contrário, pode vir a reter-se e isolar-se em maior ou menor medida dos outros, dando assim a ver traços existenciais mais ou menos estranhos. $\mathrm{O}$ classicamente chamado quadro psicopatológico infantil, bem como os trejeitos de uma criança hoje considerada portadora de um transtorno do espectro autista, tidos como a manifestação de uma suposta e simples singularidade neurológica, devem 
ser pensados no contexto desse desenvolvimento teórico, como a marca de certa forma de operar o sujeito do desejo na criança. Tal operação se dá a ver na forma como a criança circula no social e se posiciona em relação à palavra dos outros. Logo, as crianças "com necessidades educativas especiais" têm a mesma e única necessidade educativa de qualquer outra criança, isto é, fazer-se psiquicamente um lugar de sujeito de palavra numa história. Por outro lado, elas não padecem de tara neuropsicológica ou defeito educativo algum. Tampouco são condenadas a permanecerem assim como se dão a ver em virtude de uma excentricidade genômico-neurológica. Mas que mania essa de querer condenar à residência as pessoas "aî" onde elas são supostas ser de forma tão essencial!

\section{A eficácia simbólica da interpelação escolar}

Aprender os números, a ortografia, a geografia, a física, ou o que for, entranha uma mesma e única façanha - aquela de conquistar um lugar de palavra no interior de uma língua qualquer. Por exemplo, aquele que aprende a matemática passa a falar "matematiquês". Em certo sentido, aprender saberes diversos é como aprender a "se dizer" numa língua outra que não a primordial ou materna, essa que deu estofo à educaçáo primordial. A educação escolar continua, prolonga, mas também inscreve ou escreve uma diferença na educação precipitada primordialmente em braços familiares. Os políticos e pedagogos que promoveram, em algumas latitudes, a escolarização pública, laica e massiva do final do século XIX alguma coisa suspeitavam nesse sentido, embora nunca tenham lido a alocução de Freud por ocasião dos festejos do quinquagésimo aniversário da fundação do colégio secundário que ele frequentara em Viena (FREUD, [1914] 1990a). Sabiam que se tratava de fazer com que as crianças tomassem distância das tradiçôes e idiossincrasias familiares, caso contrário no lugar de uma nação só haveria uma multidão de indivíduos consumidores. Por outro lado, supunham que para bancarem o trabalho escolar as crianças deveriam já dispor de certas condiçóes pessoais. Não por acaso, a entrada na escola foi estabelecida de forma geral em torno dos seis anos, não muito mais tarde, para não se perder tempo, mas tampouco mais cedo, pois 
a criança se veria confrontada com uma demanda escolar psiquicamente desproporcionada ${ }^{10}$. Sem saber cientificamente, esses pedagogos de antanho sabiam que, em torno dessa idade, algo muda na qualidade da circulação social de uma criança. Após mais de um século de psicanálise, tais mudanças devem ser creditadas à passagem mais ou menos bem-sucedida pela experiência dos complexos de Édipo e de Castração que não é mais do que uma série de mal-entendidos inevitáveis, inerentes à educação primordial e, portanto, alheios à vida dos animais e à comunicaçáo entre máquinas. A criança que tenha se encaminhado, com maior ou menor sucesso, na elaboração infantil de uma posição dita neurótica no campo da palavra e da linguagem tem todas as chances a seu favor para emplacar o jogo escolar. A demanda escolar interpela subjetivamente (ALTHUSSER, 1976) a criança como aluno. O fato de "fazer-se aluno" - ou de brincar de ser o aluno que não é, pois ele não deixa de ser uma criança - na medida em que é "aî", nesse lugar que a escola prescreve à criança de advir para assim ser amanhã grande como os pais, pressupóe uma criança capaz de bancar o jogo, de "fazer de brincadeira". A escolarização objetiva faz das crianças alunos capazes de se prepararem para entrar, chegado o momento, no mundo dos grandes. A transformaçáo numa pessoa grande resulta de uma primeira em aluno. Ou seja, nas sociedades escolarizadas não se passa diretamente de criança à pessoa grande. A demanda escolar entranha em si mesma a interpelação da criança como aluno. A escola pede para a criança fazer de conta que é um aluno no interior do cenário escolar. Fora do perímetro ou do horário escolar, a pedagogia - ao menos aquela de antanho - sabia que uma criança voltava a ser o que era - "uma criança, filho(a) de...”. A escola expande o horizonte existencial de uma criança. Os pedagogos de antanho tomados no sonho universalista republicano de uma mesma e única escolarização para todos - para patrícios e imigrantes, pobres e ricos, brancos e negros, fiéis e agnósticos, citadinos e camponeses - pretendiam que a criança tivesse a chance de não ficar presa às fronteiras familiares, isto é, àquelas impostas pelo nascimento e pelas idiossincrasias familiares. Por um lado, a aprendizagem dos conhecimentos ensinados era o passaporte para

10 Expertos estadunidenses nunca perdem as esperanças de ensinarem os bebês a ler, o que é um belo exemplo do que entendemos ser psiquicamente desproporcionado. 
outros mundos; por outro, o fato de participar da experiência escolar junto a outros não familiares, isto é, de outra classe social, de outra religião, de outra cor de pele, etc., fazia também parte dessa viagem para o mundo dos grandes. Nesse sentido, é possível levantar a hipótese de que se Sigmund Freud não tivesse tirado proveito de ter frequentado a escola em Viena, então, nunca teria ido a Roma e "dado de cara" com Moisés na Basilica di Santo Pietro in Vincoli. Se assim fosse, ele nunca teria vindo a ser Freud - o pai inventor da psicanálise.

Por outro lado, também é verdade que os pedagogos de antanho erraram em pensar que a maioria das crianças era "normal" e, portanto, "candidata natural" à escolarização, enquanto havia uma minoria naturalmente desviante composta por idiotas, débeis, atrasados e deficientes, conforme a nomenclatura na moda. Hoje, todas as crianças são suscetíveis de terem necessidades educativas mais ou menos especiais, mas isso náo impede os pedagogos de seguirem sonhando com a normalidade de sempre. No entanto, cabe perguntar o quanto resta ainda hoje da experiência escolar de antanho e outrora reservada aos ditos normais por natureza. A degradação ou o empobrecimento da experiência escolar que hoje assola as escolas brasileiras, sejam públicas ou privadas, concerne a toda e qualquer criança. As sonhadas "normais" são aquelas que em princípio ainda conseguem dar a volta por cima, já as outras caem como moscas na arapuca (psico)pedagógica.

A experiência escolar que se preze instaura as chances de bons encontros. Por exemplo, o que teria acontecido se o pequeno Albert Camus não tivesse ido à escola na Argélia francesa? Pois, o próprio Prêmio Nobel de Literatura de 1957 respondeu à pergunta. Logo após receber a notícia de ter sido laureado, Camus afirmou na carta que endereçou ao professor da escola que frequentou em Argel - Monsieur Germain - que, se não tivesse sido por essa "mão afetuosa estendida ao garoto pobre", órfão de pai e filho de mãe analfabeta, que ele foi quando pequeno, nunca teria chegado aonde chegou (LAJONQUIÈRE, [2010] 2013, p. 67). Em outras palavras, a dita "mão afetuosa" (que é muito mais que um simples gesto) acabou embalando numa certa ressonância ambos os personagens.

A escola, tomada no sonho de possibilitar a expansão do horizonte existencial, permite a cada criança se posicionar de maneira diferente na 
dramática familiar, ou seja, possibilita a sua entrada em outras ressonâncias. Tal movimento oportuniza à criança mirar o desejo em sua travessia rumo a dizer a que veio na vida dos homens, como costumo afirmar. A criança aprende por efeito de a escola vir a expandir o horizonte de vida. Não é possível separar uma coisa da outra. O discurso (psico)pedagógico afirma precisamente o contrário. Ele reduz a experiência escolar a um simples aprendizado de conteúdos. Em outras palavras, faz da educação um simples ensino, treino de habilidades ou exercício de competências. E por isso, precisamente, que ele é hegemônico em países profundamente inigualitários como o Brasil. Ele dá caução, pretensamente científica, ao apartheid escolar (LAJONQUIÈRE, 2018).A criança supóe que o mundo adulto the esconde o saber ser grande que falta no real. Assim, tomada na esperança de vir a tê-lo quando grande, náo lhe cabe mais do que apre(e)nder aquilo que, em doses mais ou menos homeopáticas, a escola coloca à sua disposição. Assim, a criança aprende na escola não por efeito da maturação, nem graças à imitação ou repetição de comportamentos, mas por efeito da sujeição a um desejo não anônimo veiculado por um(a) professor(a) com nome e sobrenome. Sobre este, ela pretende saber, mas, como tal coisa é impossível, a criança acaba se lançando ao conhecimento desses outros mundos possíveis que a escola faz existir no horizonte (LAJONQUIÈRE, 1993). Nem todas as crianças tiram bom proveito da experiência escolar. Cada uma revela ser uma. Esta afirmação é válida para qualquer experiência humana, por exemplo, nem todos tiram proveito de uma viagem de férias, de um jantar com amigos ou do matrimônio. Mas isso não é da conta do estado. A questão é até que ponto a demanda veiculada pelo sistema escolar interpela a criança como um aluno, tanto dotado de inteligência quanto de interesse em apre(e)nder os saberes veiculados, da mesma forma que uma mãe é capaz de se endereçar a seu bebê numa posição tal que instaura as chances de a criança engatar no discurso - embora o desejo materno tampouco seja obviamente da conta do estado ou do governo. No entanto, sob o império da ilusão (psico)pedagógica a experiência escolar perde densidade simbólica, em outra palavras, a sua própria condição de experiência acaba empobrecida. O discurso (psico)pedagógico hegemônico, entretecido de saberes expertos os mais variados, retira toda eficácia simbólica (LÉVI-STRAUSS, 1958) ou toda dimensão subjetivante 
da demanda escolar. Esta não interpela mais a criança no sentido de vir a "fazer de conta". Ela passou a convocá-la a responder do lugar onde o imaginário pedagógico degradado pretende fixar à residência o sujeito do desejo. Quando se trata de uma criança tão comum como a grande maioria, ou seja, de uma daquelas que guardam em-si e para-si certa possibilidade de "levar na brincadeira" a demanda escolar, ela consegue "levar a sério" a escola fazendo disso uma experiência dos tempos da infância. Já quando se trata de outra não tão comum, isto é, presa numa certa dificuldade para se posicionar como sujeito perante a demanda, o fato de se ver confrontada a uma experiência escolar simbolicamente empobrecida a submete a um trabalho redobrado, o qual a criança bem pode estar impossibilitada de realizar. Assim, ela fica "a ver navios", nas bordas da experiência, ou se preferirem, ela passa a ser mais uma "incluída-excluída do interior".

\section{A igualdade no direito humano a se pleitear uma educação}

Educar não é "atender" a necessidades mais ou menos especiais conforme propala o discurso (psico)pedagógico hegemônico hoje reconvertido ao "inclusivismo". Esta afirmação não deve confundir-se com a negação do assento a uma pessoa de idade no ônibus ou que o estado possa se isentar de providenciar uma cadeira de rodas para alguém com problemas de locomoção. Não é desse "atendimento" que se trata. A questão é: quais são as necessidades educativas de uma criança? Creio que toda e qualquer criança tem o direito de "dizer a que veio" ao mundo, a pleitear a produção de uma diferença na vida dos homens, sendo o fato de ir à escola uma oportunidade para tanto nas nossas sociedades escolarizadas. Eis aí a igualdade no direito humano à educação!Educar, tampouco, é desenvolver ou estimular capacidades maturativas entendidas como supostas potencialidades aninhadas no organismo à espera de desabrochar "naturalmente". Educação nenhuma é o resultado da utilização de métodos supostamente adaptados às "realidades idiossincráticas" das crianças. A educação deve ser pensada para além do registro da "adaptação", peça-chave do naturalismo (psico)pedagógico. Uma mãe adapta-se ao seu filho? Ou vice-versa, um filho adapta-se à sua mãe? Uma escola aos seus alunos? Pois bem, não devemos esquecer que diferentemente dos animais somos seres desadaptados 
até com nós mesmos. Porém, outra coisa é pensar que uma mãe acolhe seu bebê recém-chegado ao mundo na posição de estrangeiro candidato a se tornar um mais-um familiar. Nesse sentido, toda escola que se preze também acolhe as crianças que nela entram numa posição, até certo ponto, estrangeira em relação à lógica escolar. Acolher o outro, o semelhante que não é meu clone, não é adaptar-se a ele. É lançar-se ou abrir-se à possibilidade de que uma ressonância venha a se estabelecer entre ambos, no interior da qual a fronteira familiar/estrangeiro virá a se deslocar uma e outra vez, produzindo efeitos que, no caso da relaçáo entre adultos e crianças, devemos chamar de efeitos educativos (LAJONQUIĖRE, 2010). Educar é lançar-se a viver essa experiência!

Nesse sentido, proponho há tempos que toda educação que se preze implica a transmissão de marcas de pertencimento a uma história em curso e, portanto, a conquista de um lugar de palavra ou de enunciaçáo no interior da mesma. Transmissão que não deve ser entendida no registro de uma simples comunicação de informaçóes, sejam elas supostamente objetivas ou pessoais. Rebaixar a transmissão de marcas de pertencimento à comunicação de conteúdos informacionais é negar a divida simbólica embutida na diferença entre as geraçōes (LAJONQUIĖRE, 1999). Entrar em ressonância educativa com uma criança dita portadora de um transtorno do espectro autista não pressupóe as mesmas iniciativas de quando se trata de uma criança bem comum. Justamente, quando de crianças não tão comuns como as outras se trata, tanto estas quantos os adultos deparam-se com não poucas dificuldades para emplacar a necessária ressonância educativa. Há décadas que tanto analistas quanto educadores, referidos de uma ou outra maneira à psicanálise, na esteira da iniciativa vanguardista de Maud Mannoni (MANNONI, 1973; LAJONQUIĖE, 1999; RODRIGUES; REIS, 2018), dão testemunho de como os entraves à ressonância educativa são singularmente contornados com certa sabedoria parcimoniosa.

A grande maioria das crianças comuns é em princípio passível de tocar a experiência escolar sem muito conflito consigo mesmas. Essa maioria pega carona na demanda escolar a partir do prolongamento tanto metonímico quanto metafórico da demanda educativa parental. Isto não justifica, entretanto, estarmos autorizados a degradar perversamente a experiência 
escolar. Não devemos esquecer que toda degradação além da conta faz extrapolar as estadísticas do chamado fracasso escolar (LAJONQUIÈRE, 2019).Por outro lado, as crianças não tão comuns como as outras esbarram justamente aí onde a grande maioria consegue mais ou menos "levar na brincadeira”. Mas isso não significa que a escola o faz de propósito para não "incluir" todas as crianças ou que as escolas devam ser transformadas de cabo a rabo, como às vezes é dito à ligeira. Uma demanda escolar que se preze náo pode não interpelar a criança como aluno. $\mathrm{O}$ algoritmo educativo não deve ser neuroticamente confundido com nenhuma representação imaginária de autoritarismo pedagógico mais ou menos tradicional. Justamente, no caso da inclusão de crianças com dificuldades para se situarem num universo regido pela demanda escolar, a experiência vem mostrando que a participação de um adulto acompanhante disposto a fazer as vezes de um tradutor fronteiriço permite a instalação de uma certa ressonância e, portanto, oportuniza que a criança venha a bancar um lugar de aluno". Porém, a introdução deste novo personagem no cenário escolar não deve ser vista como se fosse a "técnica" capaz de garantir a inclusão escolar. Quando assim é feito, então, o papel do "acompanhante" vê-se reduzido à "contenção" da "criança de inclusão". No limite, a contenção perfeita seria aquela que anulasse a presença mesma da criança na sala. Dessa forma, o ideário é aquele formatado no campo da psiquiatria pela via da introdução massiva dos neurolépticos, o da indiferença generalizada (CAPONI, 2019).A escolarização presa numa ideologia naturalizante que não lhe é em absoluto privativa, barrou durante um século a entrada na escola de crianças não tão comuns como as outras. Elas foram trancadas ora em casa, ora em instituiçóes ditas mais ou menos especializadas no "atendimento" de crianças "anormais". Porém, há meio século uma série de ideias aportadas pela psicanálise, pela psicologia institucional e pela antipsiquiatria animou não poucos pioneiros do desenclaustro asilar. A lista é longa, mas não posso deixar de lembrar de Maud Mannoni que junto a outros abriu as portas, em 1969, da École Expérimentale de Bonneuil-surMarne.Mais tarde, a Declaração de Salamanca de 1994 abriu para todas as crianças as portas das escolas. Porém, isto não fez barragem à ideologia

I I O desenvolvimento desta ideia será motivo de um próximo artigo. 
naturalizante que antes impedia a entrada das crianças nas escolas. Infelizmente, a velha suspeita de "anormalidade" agora reciclada acabou generalizando-se, haja vista a mania atual em se fabricar crianças "laudadas" na sua suposta diferença.

Ironia do destino para uma declaração redigida em tão distinguida cidade espanhola... Ou talvez deva dizer que se trata da inevitável insistência do sonho naturalizante: Quod natura non dat, Salmantica non prestat ${ }^{2}$.

\section{Referências}

ALTHUSSER, L. Positions. Paris: Éditions Sociales, 1976.

ARIÈS, Ph. [1960]. L'enfant et la vie familiale sous l'Ancien Régime. Paris: Seuil, 1973.

BOURDIEU, P.; CHAMPAGNE, P. Les exclus de l'intérieur. In: BOURDIEU, P. La Misère du monde. Paris: Seuil, 1993. p. 597-608.

CAPONI, S. Uma Sala Tranquila. Neurolépticos para uma biopolítica da indiferença. São Paulo: Editora LiberArs, 2019.

CRESPIN, G. L'épopée symbolique du nouveau-né. Toulouse: Éditions Érès, 2010.

FANIZZI, C.; LAJONQUIÈRE, L. (ed.). O discurso medicalizante e a educação: o sujeito no impasse. Estilos da Clínica, São Paulo, v. 25, n. 1, p. 105-122, maio 2020. FREUD, S. [1914]. Algumas Reflexóes Sobre a Psicologia do Escolar. In: FREUD, S. Ediçáo Standard Brasileira das Obras Psicológicas Completas de Sigmund Freud. Volume 13. Rio de Janeiro: Imago Editora, 1990a. p. 285-289.

FREUD, S. [1925]. Inibiçôes, sintomas e ansiedade. In: FREUD, S. Edição Standard Brasileira das Obras Psicológicas Completas de Sigmund Freud. Volume 20. Rio de Janeiro: Imago Editora, 1990b, p. 107-210.

FREUD, S. [1927]. O futuro de uma ilusão. In: FREUD, S. Ediçáo Standard Brasileira das Obras Psicológicas Completas de Sigmund Freud. Volume 21. Rio de Janeiro: Imago Editora, 1990c. p. 15-79.

FREUD, S. [1929]. O mal-estar na civilização. In: FREUD, S. Ediçáo Standard Brasileira das Obras Psicológicas Completas de Sigmund Freud. Volume 21. Rio de Janeiro: Imago Editora, 1990d. p. 81-177.

IMBERT, F. La question de l'éthique dans le champ éducatif. Vigneux: Matrice, 1993.

LAJONQUIÈRE, L. (ed.). Infância e ilusão (psico)pedagógica. Petrópolis: Editora Vozes, 1999.

12 Aquilo que a natureza não deu de entrada, a universidade de Salamanca não dará depois (tradução libre). 
LAJONQUIÈRE, L. (ed.). A psicanálise e o debate sobre o desaparecimento da infância. Educaçáo \& Realidade, Porto Alegre, v. 31, n. 1, p. 89-106, jun. 2006.

LAJONQUiÈRE, L. (ed.). Niños extraños. En Cursiva. Revista Temática, Buenos Aires, v. 4, p. 41-46, abr. 2008a.

LAJONQUIÈRE, L. (ed.). De como jogamos fora a criança com a água suja do amoródio. In: COLÓQUIO INTERNACIONAL DO LEPSI, 7., São Paulo, nov. 2008b. Anais eletrônicos [...]. São Paulo: LEPSI, 2008. Disponível em:

http://www.proceedings.scielo.br/scielo.php?script=sci_arttext\&pid=MSC000000003200800010 0009\&lng=pt\&nrm=iso\&tlng=pt. Acesso em: 10 set. 2020.

LAJONQUIÈRE, L. (ed.). [2010]. Figures de l'infantile. Paris: L'Harmattan, 2013.

LAJONQUIÈRE, L. (ed.). A mestria da palavra e a formação de professores. Educaçáo \& Realidade, Porto Alegre, v. 36, n. 3, p. 849-865, dez. 2011. Disponível em https://seer.ufrgs.br/ educacaoerealidade/article/view/13316/14336. Acesso em: 10 set. 2020.

LAJONQUIÈRE, L. (ed.). De Victor de l'Aveyron à Helen Keller: du bon usage de la parole dans l'éducation des enfants. Cliopsy. Revue électronique, Paris, n. 11, p. 55-67, 2014. Disponível em https://www.revuecliopsy.fr/wp-content/uploads/2014/05/055-c11-ok-Leandro.pdf Acesso em: 10 set. 2020.

LAJONQUIÈRE, L. (ed.). Sigmund Freud e o interesse pedagógico da psicanálise. In: KUPERMANN, D. (org.). Por que Freud? São Paulo: Zagodoni, 2017a. p. 243-254.

LAJONQUIÈRE, L. (ed.). Do interesse epistemológico dos estudos psicanalíticos na educação. In: PEREIRA M. (org.). Os sintomas na educaçáo de hoje: que fazemos com isso? Belo Horizonte: Scriptum, 2017b. p. 32-38.

LAJONQUIÈRE, L. (ed.). As ilusóes (psico)pedagógicas e o sonho de uma escola para todos. In: ARREGUY, M. E. (org.). Racismo, capitalismo e subjetividade: leituras psicanalíticas e filosóficas. Niterói: EDUFF, 2018. p. 59-68.

LAJONQUIẼRE, L. (ed.). Quando o sonho cessa e a Ilusão Psicopedagógica nos invade, a escola entra em crise. Notas comparativas Argentina, Brasil, França. Revista ETD, v. 21, n. 2, p. 297-315, 2019.

LACAN, J. [1953-1954]. Le Séminaire Livre I. Paris: Seuil, 1975.

LACAN, J. [1959-1960]. Le Séminaire Livre VII. Paris: Seuil, 1986 b.

LACAN, J. [1969]. Deux notes sur l'enfant. Ornicar? Paris, n. 37, p. 13-14, 1986 b.

LACAN, J. [1968-1969]. Le Séminaire Livre XVI. Paris: Seuil, 2006.

LÉVI-STRAUSS, C. Anthropologie structurale. Paris: Plon, 1958.

MANNONI, M. Éducation impossible. Paris: Seuil, 1973.

PATTO, M. H. S. Psicologia e ideologia. São Paulo: Queiroz Editor, 1984. 
PATTO, M. H. S. A produção do fracasso escolar. Histórias de submissão e rebeldia. São Paulo: Queiroz Editor, 1993.

RODRIGUES, R.; REIS, M. A ilusão (psico)pedagógica e o empobrecimento das experiências educativas (Entrevista com Leandro de Lajonquière). Estilos da Clínica, São Paulo, v. 23, n. 2, p. 430-450, 2018.

ROSSET, C. L’anti-nature - Éléments pour une philosophie tragique. Paris: PUF, 1973.

Recebido: 14/05/2020

Aceito: 21/06/2020 


\section{For an inclusive school or a necessary subversion of hegemonic (psycho)pedagogical discourse}

\section{Abstract}

In order to inquire about the functioning and status of the implementation of the "inclusive school", the text presents and develops the notion of (psycho)pedagogical illusion. This is considered a key part of the naturalizing pedagogical ideal. Thus, it is claimed that the old pedagogical naturalism that established an essential difference between "normal" and "abnormal" - enough for them to be prevented from going to ordinary schools -, today, paradoxically gives rise to the idea of "special educational needs", proposed by the Salamanca Statement (1994). This notion gives scope, in turn, for the practices of "diagnosing" and "labeling" children. Such a gesture, particularly widespread in Brazil, impoverishes the school experience of children, condemning them to the condition of "excluded from within". It is proposed, then, in the context of psychoanalytic studies in education, the epistemological subversion of the naturalizing ideal, responsible for the obstacles imposed on the event of a worthy education.

Keywords: Inclusive education. Psychoanalysis and education. Naturalistic thinking. Pedagogical essentialism. Psychopedagogy. 